Gut, 1988, 29, 537-543

Case report

\title{
Pathophysiological study of diarrhoea in a patient with medullary thyroid carcinoma. Evidence against a secretory mechanism and for the role of shortened colonic transit time
}

\author{
JC RAMBAUD, R JiAN, B FLOURIÉ, M HAUTEFEUILlE, M SALMERON, \\ F THUILliER, A RUSKONÉ, C FLORENT, F CHAOUI, AND J-J BERNIER
}

From the Unité de Recherches sur les Fonctions Intestinales, et la Nutrition (INSERM U290), Hôpital Saint-Lazare, Paris, France

SUMMARY Intubation techniques and scintigraphic studies were used to determine the origin and mechanism of diarrhoea in a patient with medullary thyroid carcinoma, high plasma immunoreactive calcitonin and normal circulating serotonin, substance $P$ and prostaglandins $E_{2}$ and $F_{2 \alpha}$. Normal function of the small intestine was found for the following: (a) absorption tests; (b) water and electrolyte absorption in the proximal jejunum; (c) 24 hour flow rate and composition of fluid entering the colon and (d) gastric emptying rate and small intestinal progression of a normal meal. By contrast, colonic function was markedly impaired in three ways: (a) water absorption was decreased by half; (b) as the main excreted solutes were organic acids, a large electrolyte gap was recorded in faecal water, and (c) colonic transit time of the meal marker was very short, and was in agreement with the rapid transit of ingested radioopaque markers. These data strongly suggest that decreased absorption in the colon secondary to a motor disturbance is the main mechanism of diarrhoea in this case of medullary thyroid carcinoma, while calcitonin induced small intestinal fluid secretion suggested earlier is either non-existent, or only of minor importance.

Diarrhoea is seen in $28-39 \%$ of patients with medullary thyroid carcinoma (MTC). ${ }^{12}$ The link between tumoral secretion and diarrhoea is obvious as the latter is more frequent in patients with advanced disease, ${ }^{34}$ immediately disappears after complete surgical resection of the lesion $^{35}$ and relapses in cases of tumour recurrence. ${ }^{3}$ Because an acute intravenous infusion of calcitonin induces jejunal and ileal secretion of water and electrolytes in normal man, ${ }^{6}$ the diarrhoea accompanying MTC is usually considered to result from a secretory process induced by raised circulating calcitonin. ${ }^{7}$ Calcitonin production by MTC is a constant feature, however, ${ }^{8}$

Address for correspondence: Dr Jean-Claude Rambaud. INSERM U290, Hôpital Saint-Lazare, 107 bis, rue du Faubourg Saint-Denis, 75475 Paris Cedex 10, France.

Received for publication 28 September 1987. whether or not diarrhoea is present, and its plasma concentration does not seem to correlate with intestinal dysfunction. ${ }^{+}$

We report here a pathophysiological study of the increased faecal fluid losses in a case of MTC with diarrhoea and hypercalcitoninaemia. The results do not support the presence of a secretory mechanism, but strongly suggest that diarrhoea was the result of dysfunction of the colon caused by a marked shortening of the transit time of the intraluminal contents.

\section{Case history}

A 41 year old man was admitted to hospital for chronic diarrhoea which had lasted for eight years. He passed six to 15 watery stools per day; motions were urgent and mainly postcibal, and the faeces 
often contained undigested foods absorbed during the preceding meal. Four years previously, a thyroid nodule, several enlarged cervical lymph nodes and a calcified lung miliary had been found. Subtotal thyroidectomy was done, and pathological examination revealed a typical medullary carcinoma with amyloid stroma. Personal and familial past histories were unremarkable. On admission, the patient had lost $20 \mathrm{~kg}$ of weight. There were frequent abdominal borborygmi and slight hepatomegaly. Several cervical lymph nodes were enlarged. In other respects, physical examination was normal, and blood pressure was $120-80 \mathrm{~mm} \mathrm{Hg}$.

Haemogram, plasma glucose, serum urea, electrolytes, calcium, inorganic phosphorus, and 24 hour urinary calcium and magnesium outputs were normal. Carmin red oro-anal transit time was $150 \mathrm{~min}$. Daily stool number and weight (mean of three days) were 12 and $1003 \mathrm{~g}$ respectively, and decreased to four and $567 \mathrm{~g}$ during the daily oral administration of $43 \mathrm{mg}$ codeine and $36 \mathrm{mg}$ codethyline. In the absence of these drugs, stool weight dropped to $420 \mathrm{~g}$ during the second day of a 48 hour fast. Faecal fat (mean of three days) was $5.8 \mathrm{~g} / \mathrm{d}$. D-xylose and Schilling's tests were normal, and so was the cholyl $-{ }^{14} \mathrm{C}$-glycyl breath test. Sigmoidoscopy, barium enema, and follow through showed no morphological abnormalities, but the swallowed barium reached the caecum and rectum within 30 and 60 minutes respectively. Liver and skeletal scintiscans revealed several secondary deposits. Patient immunoreactive plasma calcitonin was markedly raised $(266 \mathrm{ng} / \mathrm{ml}$, normal $<0 \cdot 25 \mathrm{ng} /$ $\mathrm{ml}$ ). There was a superposition of the dilution curve for the patient's immunoreactive plasma calcitonin and the standard curve for calcitonin radioimmunoassay with synthetic human calcitonin. No salmon like calcitonin was detected by a specific radioimmunoassay. The concentration of patient's calcitonin, assessed in the same plasma sample by a biological assay, ${ }^{9}$ was abnormally high $(115 \mathrm{ng} / \mathrm{ml}$, the normal level being undetectable in this assay) although lower than the result given by the radioimmunoassay. Plasma concentrations of immunoreactive prostaglandins $E_{2}(11 \mathrm{pg} / \mathrm{ml})$ and $F_{2}$ $(9 \mathrm{pg} / \mathrm{ml})$, substance $P$, gastrin, vasoactive intestinal peptide, somatostatin, and parathormone were all

Table 1 Jejunal perfusion study with triple lumen tube

\begin{tabular}{llll}
\hline & $\mathrm{H}_{2} \mathrm{O}(\mathrm{ml})^{*}$ & $\mathrm{Na}(\mu \mathrm{mol})^{*}$ & $\mathrm{Cl}(\mu \mathrm{mol})^{*}$ \\
\hline Patient & +0.08 & $+7 \cdot 8$ & $+3 \cdot 6$ \\
$\quad$ Controls & $-0 \cdot 77(0 \cdot 84)$ & $-89(98)$ & $-131(140)$ \\
$\quad($ mean $(2 \mathrm{SD}) \mathrm{n}=18)$ & & & \\
\hline
\end{tabular}

*Dates are expressed per $\min$ and per $25 \mathrm{~cm}$; +=net secretion; $-=$ net absorption. normal. So were plasma serotonin and cortisol, and 24 hour urinary outputs of 5-hydroxy-indolacetic acid, of catecholamines and of their metabolites vanillylmandelic and homovanillic acids. The total plasma thyroxin concentration was low, but triiodothyronine and thyroid stimulating hormone concentrations were normal.

\section{Methods}

\section{SUBJECTS}

The patient and healthy volunteers were studied after obtaining their written informed consent and the approval of the local ethic committee.

\section{INTESTINAL PERFUSION STUDIES}

\section{Jejunal perfusion}

Transintestinal water and electrolyte transport in the absence of non-electrolyte solutes was measured in the proximal jejunum by the triple lumen tube perfusion technique." The test solution $(130 \mathrm{mM}$ $\mathrm{NaCl}, 20 \mathrm{mM} \mathrm{KC1}$, polyethylene glycol 4000 PEG 1 $\mathrm{g} / \mathrm{l}$ ) was perfused at a rate of $8 \mathrm{ml} / \mathrm{min}$. The mixing and test segments were $20 \mathrm{~cm}$ and $25 \mathrm{~cm}$ long, respectively. Stimulation of sodium and water transport by glucose was studied distal to an occluding balloon (test segment $25 \mathrm{~cm}$ ). The test solutions (130 $\mathrm{mM} \mathrm{NaCl}, 5 \mathrm{mM} \mathrm{KC1}$, PEG $10 \mathrm{~g} / 1,30 \mathrm{mM}$ mannitol or glucose) were perfused at a rate of $10 \mathrm{ml} / \mathrm{min}$. Results of these two studies were compared with those previously obtained in our laboratory in 18 and 10 healthy volunteers, respectively. ${ }^{111}$

\section{Slow marker perfusion studies}

The overall small and large intestinal transport of water and electrolytes was determined by simultaneous measurement for $24 \mathrm{~h}$, by the slow marker perfusion technique, of the flow rate and composition of the fluid entering the jejunum and leaving the terminal ileum, and by collecting all stools during the three days preceding the perfusion study. This study was done with a previously described several lumen tube. ${ }^{12}$ Tube 1 was used to perfuse, in the duodenum $15 \mathrm{~cm}$ proximal to the angle of Treitz, ${ }^{57} \mathrm{Co}$-vitamin $\mathrm{B}_{12}(4 \mu \mathrm{Ci} / \mathrm{l}$ in $\mathrm{NaCl} 150 \mathrm{mM})$ at a constant rate of 0.5 $\mathrm{ml} / \mathrm{min}$. Tube 2 , ending $15 \mathrm{~cm}$ below near the angle of Treitz, allowed sampling of intestinal contents at the same rate of $0.5 \mathrm{ml} / \mathrm{min}$. Tubes 3 and 4 , ending $30 \mathrm{~cm}$ apart, were used to perfuse ${ }^{14} \mathrm{C}$-PEG $(60 \mu \mathrm{Ci} / 1$ in $\mathrm{NaCl} 150 \mathrm{mM}) 40 \mathrm{~cm}$ above the ileocaecal function at a constant rate of $0.25 \mathrm{ml} / \mathrm{min}$ and to aspirate intestinal contents as completely as possible in the terminal ileum. All four tubes were tracted by tube 5 ended with a mercury bag that could be inflated with air to hasten tube progression. When the bag had reached the caecum, it was deflated and the subject was asked to maintain a semirecumbant position to 
avoid further progresson of the tube. Tubes 1 and 2 were bound to the tracting tube in such a way that they could be separated from it when their distal openings were correctly positioned. The number of control healthy volunteers was limited to three, as the ileal results were within the range of values found by us $^{13}$ and others ${ }^{14}$ using cold PEG as non-absorbable ileal marker. During the whole study, the patient and the controls received the same low fibre diet containing $2225 \mathrm{kcal}, 74 \mathrm{~g}$ proteins, $81 \mathrm{~g}$ lipids, $300 \mathrm{~g}$ carbohydrates, and $1500 \mathrm{ml}$ water $/ 24 \mathrm{~h}$.

\section{Analytical procedures}

Sodium and potassium were measured by flame photometry, and chloride and bicarbonate, by a colorimetric method on a Technicon auto-analyser. Stool water volume was calculated from the difference between fresh and dry weights. Stool electrolytes, ammonium and total organic acids were measured according to Goiffon et al. ${ }^{15}{ }^{16}$ Osmolality of extracellular stool water obtained by centrifugation was determined immediately after their recovery

Table 2 Jejunal perfusion studies distal to an occluding balloon*

\begin{tabular}{|c|c|c|c|}
\hline & $\mathrm{H}_{2} \mathrm{O}(\mathrm{ml})$ & $\mathrm{Na}(\mu \mathrm{mol})$ & $C l(\mu m o l)$ \\
\hline \multicolumn{4}{|c|}{ Mannitol solution } \\
\hline Patient & $0 \cdot 0$ & -10 & -52 \\
\hline Controls $\dagger$ & $-0.27(1.04)$ & $-68(162)$ & $-69(146)$ \\
\hline \multicolumn{4}{|c|}{ Glucose solution } \\
\hline Patient & $-2 \cdot 6$ & -328 & -369 \\
\hline Controls $†$ & $-3.37(1.56)$ & $-407(236)$ & $-423(266)$ \\
\hline \multicolumn{4}{|c|}{$\Delta$ net movement $\ddagger$} \\
\hline $\begin{array}{l}\text { Patient } \\
\text { Controls } \dagger\end{array}$ & $\begin{array}{l}-2 \cdot 6 \\
-3 \cdot 6(2 \cdot 4)\end{array}$ & $\begin{array}{l}-318 \\
-477(376)\end{array}$ & $\begin{array}{l}-317 \\
-490(380)\end{array}$ \\
\hline
\end{tabular}

*Data are expressed per min and per $25 \mathrm{~cm}$.

† Mean (2SD) $n=10$.

$\ddagger$ Difference in water and electrolyte transport when glucose replaces mannitol in the perfused solution. Sign $-=$ increased absorption. with a Fiske osmometer. Results were compared with those obtained in five healthy volunteers whose stools were appropriately diluted before centrifugation. ${ }^{57} \mathrm{Co}$ and ${ }^{14} \mathrm{C}$ radioactivities were measured with a gamma counter (CGR-SAIP France) and liquid scintillation counter (Intertechnique France), respectively.

\section{Calculations}

Water and electrolyte movements and the enhancement of electrolyte and water transport by glucose during segmental perfusion studies, and flow rates at the ligament of Treitz and in the distal ileum, were calculated according to the usual formulae. ${ }^{1111}$

\section{GUT TRANSIT TIME}

\section{Radioopaque markers}

The mean transit time of radioopaque markers was determined by the single stool method ${ }^{17}$ before codeine and codethyline administration and during this treatment and compared with values obtained without any treatment in 15 healthy volunteers.

\section{Scintigraphic study}

Gastric emptying and intestinal progression of a normal solid-liquid meal were investigated in the patient according to a previously published technique ${ }^{18}$ using ${ }^{* / m}$ technetium sulphur colloid $\left({ }^{4 \% m} \mathrm{Tc}\right)$ as marker. Results obtained were compared with those previously found in 16 healthy controls. ${ }^{18}$

\section{Results}

JEJUNAL AND ILEAL SEGMENTAL PERFUSION

In the jejunum, water, sodium and chloride movements during the perfusion of a pure electrolyte solution with the triple lumen tube were within normal confidence limits (Table 1). During the jejunal perfusion distal to an occluding balloon,

Table 3 Twenty four hour flow rates of water and electrolytes at the angle of Treitz, in distal ileum, and in stools

\begin{tabular}{|c|c|c|c|c|c|}
\hline & $\mathrm{H}_{2} \mathrm{O}(\mathrm{ml})$ & $\mathrm{Na}(\mathrm{mmol})$ & $K(\mathrm{mmol})$ & $\mathrm{Cl}(\mathrm{mmol})$ & $\mathrm{HCO}_{3}(\mathrm{mmol})$ \\
\hline \multicolumn{6}{|l|}{ Treitz angle } \\
\hline Patient & 4265 & 455 & 40 & 436 & 63 \\
\hline Controls (range, $n=3$ ) & $3765-4959$ & $391-553$ & $39-50$ & $405-437$ & $47-59$ \\
\hline \multicolumn{6}{|l|}{ Distal ileum } \\
\hline Patient & 2280 & 306 & 16 & 235 & 92 \\
\hline Controls (range, $n=3)^{*}$ & $2127-2761$ & $261-365$ & $15-39$ & $194-338$ & $40-86$ \\
\hline \multicolumn{6}{|l|}{ Stools } \\
\hline Patient & 1171 & 59 & 40 & 88 & 18 \\
\hline Controls (range, $n=3$ ) & $80-222$ & $1 \cdot 2-11 \cdot 5$ & $7 \cdot 5-23 \cdot 5$ & $1 \cdot 1-5 \cdot 5$ & $0 \cdot 2-1 \cdot 5$ \\
\hline
\end{tabular}

${ }^{*}$ In four other controls in whom cold PEG was used instead of ${ }^{14} \mathrm{C}-\mathrm{PEG}$ as marker of water movements, flow rates in distal ilcum per $24 \mathrm{~h}$ were 2080 (140) $\mathrm{ml}, 280$ (15) mmol, 14 (1) mmol, 235 (13) mmol, and 56 (12) mmol (mean SE) for water, sodium, potassium, chloride, and bicarbonate respectively. ${ }^{13}$ 
Table 4 Twenty four hour movements of water and electrolytes in the small intestine (jejunum +ileum) and the colon*

\begin{tabular}{|c|c|c|c|c|c|}
\hline & $\mathrm{H}_{2} \mathrm{O}(\mathrm{ml})$ & $\mathrm{Na}(\mathrm{mmol})$ & $K(\mathrm{mmol})$ & $\mathrm{Cl}(\mathrm{mmol})$ & $\mathrm{HCO}_{3}(\mathrm{mmol})$ \\
\hline \multicolumn{6}{|l|}{ Small intestine } \\
\hline Patient & -1985 & -149 & -24 & -201 & +29 \\
\hline Controls (range, $n=3$ ) & -1638 to -2308 & -130 to -214 & -11 to -24 & -199 to -211 & -7 to -13 \\
\hline \multicolumn{6}{|l|}{ Colon } \\
\hline Patient & -1119 & -247 & +24 & -147 & -74 \\
\hline Controls (range, $n=3$ ) & -2047 to -2539 & -260 to -354 & -7 to -15 & -193 to -332 & -40 to -84 \\
\hline
\end{tabular}

*Sign $-=$ absorption, sign $+=$ secretion.

water, sodium and chloride movements were also normal with both mannitol and glucose containing solutions, whereas glucose absorption was slightly depressed. Stimulation of jejunal sodium and water absorption by glucose, estimated as the difference observed between sodium and water movements with the glucose and mannitol containing solutions, was normal (Table 2).

\section{SLOW MARKER PERFUSION}

The 24 hour fluid and electrolyte flow rates at the ligament of Treitz and in the distal ileum were within the normal range, except for the bicarbonate rates which were slightly increased at both levels (Table 3 ). The overall jejunoileal transport of water and ions, calculated as the difference between the flow rates in the distal ileum and at the angle of Treitz, was normal except for bicarbonate (Table 3). Faecal water and electrolyte outputs were raised (Table 3 ). Comparison of ileal and faecal outputs showed that colonic water absorption was markedly low, whereas sodium absorption was only slightly below the lower control limit (Table 4). There was a mild colonic secretion of potassium, instead of absorption in the controls, and chloride absorption was moderately reduced (Table 4).

Faecal water osmolality, measured in four different stools, ranged between 362 and $380 \mathrm{mosmol} / \mathrm{kg}$.
The solute content of the same faecal water samples is given in Table 5. Although 24 hour faecal organic acid output could not be calculated exactly from these data, it is clear that it was markedly raised, compared with normal controls. Moreover, it is noteworthy that faecal water osmolality was much higher than the product $[\mathrm{Na}+\mathrm{K}] \times 2$, where $[\mathrm{Na}]$ and $[\mathrm{K}]$ were the concentrations of sodium and potassium in the same faecal water samples, respectively.

\section{GUT TRANSIT TIME}

Mean total transit time of radioopaque markers was $3.6 \mathrm{~h}$ (normal values $44(15) \mathrm{h}$ ) without treatment, and $6.5 \mathrm{~h}$ and $8.3 \mathrm{~h}$ under $43 \mathrm{mg}$ codeine and $36 \mathrm{mg}$ codethyline. Scintigraphic study of the progression of the solid-liquid meal showed a normal gastric emptying rate (emptying half time: 84 min, normal 68 (31) min, mean (SD), range 30-135, $\mathrm{n}=16$ ). Progression of the meal through the small intestine was almost normal. The terminal ileum was reached 10 minutes after the end of meal ingestion (normal: 20 (16) min, range $5-65, n=15$ ), and the percentage of ingested radioactivity found in the colon was slightly raised until the 90th minute, when it was $19 \%$ (normal: $9 \cdot 7$ $(4 \cdot 8) \%$, range $2-17, n=16)$. After this time, the abnormalities of colonic transit described below made further quantification of small bowel emptying impossible, because of colonic superposition. Indeed,

Table 5 Solute concentrations and osmolality of extracellular stool water*

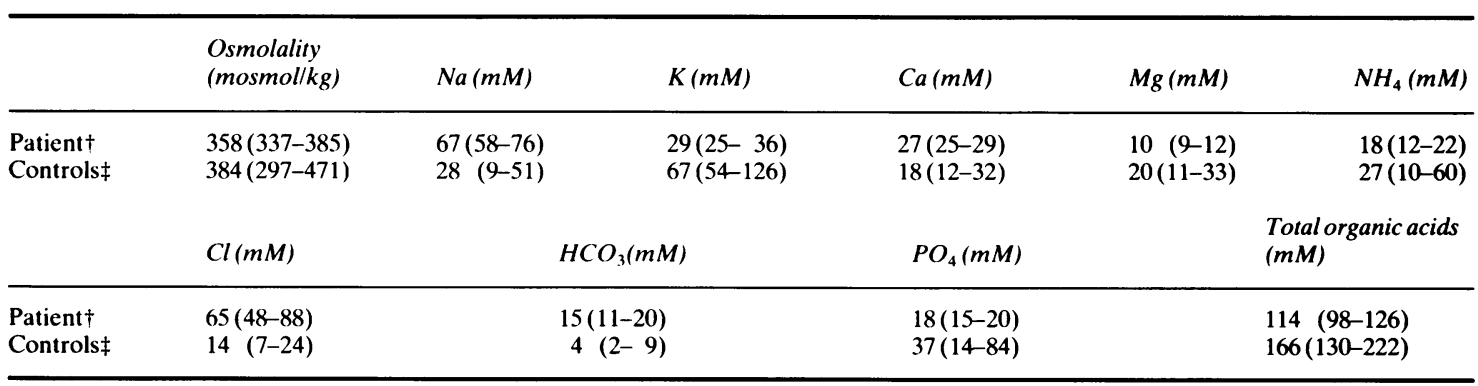

* Results are expressed as means; range is in brackets; $†$ Four individual stools of the patient were assayed; $\ddagger$ Controls were the one day stool of five healthy subjects. 
the radioactivity entering the caecal area was almost immediately expelled toward the colonic right angle, and after 90 minutes, the marker was propulsed by successive waves up to the sigmoid area. At $115 \mathrm{~min}$, the patient had a motion containing meal marker as intracolonic activity immediately decreased thereafter (Figure). In the 16 normal controls, the meal marker progressively accumulated in the caecal area and was never propulsed beyond the colonic right angle during the 150 minutes of the study.

\section{Discussion}

Previous pathophysiological studies of two cases of MTC with diarrhoea led to the conclusion that the increased faecal output of water and electrolytes was caused by the impairment of small intestine function. ${ }^{1920}$ In our patient, however, the 24 hour flow rates measured for water and electrolytes at the end of the ileum do not support this conclusion. Apart from a slight excess for bicarbonate, they were within the normal range determined in healthy controls. As water and electrolyte flow rates at Treitz's angle were also normal (except for the slightly raised bicarbonate), the overall handling of water and ions in the small bowel of our patient was normal.

The results of the segmental perfusion studies in the proximal jejunum fit this conclusion as the transport of water and electrolytes from a pure electrolyte solution was normal, as was the stimulatory effect of glucose on water and sodium absorption. These findings are in agreement with those of Isaac et al. $^{19}$

As the entry of fluid in the colon of our patient was normal, increased faecal water losses were caused by insufficient net absorption in this organ. In the case studied by Cox et al,,$^{20}$ ileal fluid flow rate was moderately high, but still well under the maximal capacity of the colon to absorb water. ${ }^{2122}$ The case report of Norman and Otnes ${ }^{23}$ illustrates both the possibility of mild bowel dysfunction in MTC with diarrhoea, and its lack of significance in terms of overall intestinal fluid handling. Thus, after an unjustified colectomy, the daily ileostomy output was only $700 \mathrm{~g}$, but dropped to $350 \mathrm{~g}$ after resection of the thyroid tumour.

The sum of the sodium and potassium concentrations in stool water of our patient was rather low, whereas faecal water osmolality was greater than that of plasma. Consequently, there was a large gap between faecal water osmolality calculated from its electrolyte content, ${ }^{724}$ and the osmolality actually measured. Organic acids accounted for most of this 'solute gap'. The pathophysiology of diarrhoea in MTC therefore appears very different from that of secretory diarrhoeas, such as pancreatic cholera. ${ }^{24}$

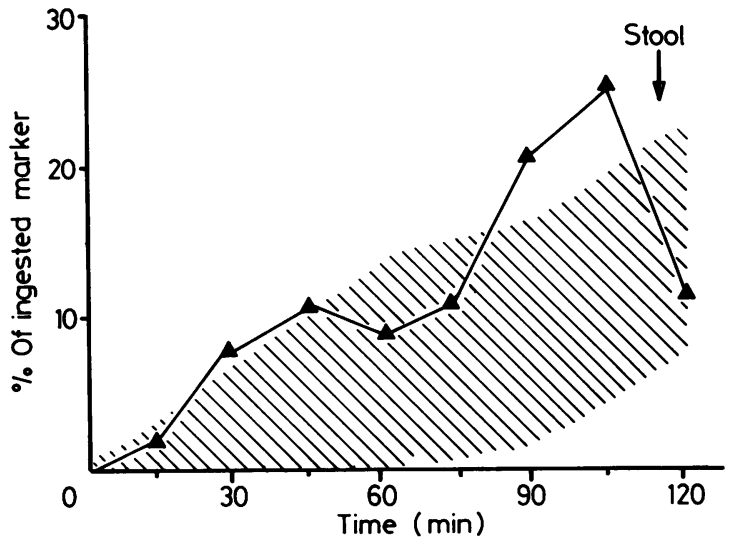

Figure Percentage of ingested marker counted in the colonic area. The first postprandial stool $(+115 \mathrm{~min})$ eliminated $50 \%$ of the intracolic activity. Hatched area $=$ range of normal values obtained in 16 healthy subjects (18); none of them had a motion during the study.

The organic acid concentration of faecal water in our patient was similar to that found in our normal controls and in those studied by Rubinstein t $_{\text {al }}{ }^{25} \mathrm{On}$ the other hand, faecal water output was markedly higher than in normal subjects; thus, although the output of 24 hour faecal organic acid could not be exactly calculated from our data, it was obviously very high. This in turn could be because of either an increased production of volatile fatty acids by colonic bacteria or decreased absorption in the colon, secondary to the very short transit time of colonic contents. ${ }^{26}$ Excess intracolonic fermentation of carbohydrates was unlikely, because in our patient, as in most of the others studied, ${ }^{527}$ functional tests evaluating the absorption of nutrients in the small bowel were normal. Our scintigraphic investigation of the gut transit of a solid-liquid meal provides an explanation for these findings, as it showed that gastric emptying and small bowel transit were within nearly normal limits. By contrast, the very short transit time of colonic contents found in other patients studied with barium follow through ${ }^{5}$ was confirmed in the present case by measuring gut transit time with radioopaque markers, and by scintigraphic assessment of the progression of a normal meal.

Diarhhoea in MTC has been repeatedly related to increased circulating concentrations of calcitonin ${ }^{7190}$ because this hormone is known to stimulate secretion by the small intestine mucosa, when acutely administered to normal man. ${ }^{6}$ Our present findings and those of Isaac et al $^{19}$ do not support this hypothesis. It is not known why, in these two patients, the marked increase in circulating immunoreactive calcitonin $(266 \mathrm{ng} / \mathrm{ml}$ and $278 \mathrm{ng} / \mathrm{ml} \mathrm{[19]} v 1.8$ to $2.4 \mathrm{ng} / \mathrm{ml}$ in 
Gray et al acute experiments [6]) failed to induce secretion of water and ions in the jejunum. Calcitonin has been shown to be present in several different molecular forms in MTC. ${ }^{28}$ In our case the result of the biological assay ruled out the possibility that immunoreactive calcitonin was mainly present in biologically inactive form. One explanation might be tachyphylaxia of intestinal mucosa during chronic hypercalcitoninaemia, as a similar mechanism was shown to account for the absence of hypocalcaemia in MTC. ${ }^{29}$

It is also unlikely that hypercalcitoninaemia was responsible for the striking reduction of colonic transit time in the present case, as in all other patients with MTC and diarrhoea. ${ }^{527}$ Diarrhoea has not been reported as a side effect in patients treated chronically with calcitonin for osteoporosis or Paget's disease, although acute intravenous infusion of about a one day therapeutic dose can induce diarrhoea in the postcibal period..$^{30}$ Circulating prostaglandins $\mathrm{E}_{2}$ and $F_{2 \alpha}$, serotonin and substance $P$ can be increased in patients with MTC $^{31-34}$ and could be involved in the pathogenesis of diarrhoea. Some of the patients with MTC and diarrhoea, including our present case, however, have normal circulating concentrations of these agents.

Thus, at least in the present case, the diarrhoea associated with MTC does not seem to be caused by a secretory process ir duced by hypercalcitoninaemia. A dysfunction of the colon, probably secondary to the marked shortening of transit time in this organ, appears to be the main mechanism causing diarrhoea. The humoral agent responsible for this motility disorder remains to be discovered.

The authors wish to thank Dr P Skrabanek for substance $P$ assay, Dr C Sautier for stool water studies, Mrs M Maurel, M Rongier and C Franchisseur for skilful technical assistance, Mrs I Wohnlich for bibliographic research, and Miss F Berthet for typing the manuscript.

\section{References}

1 Williams ED. Diarrhoea and thyroid carcinoma. Proc $R$ Soc Med 1966; 59: 602-3.

2 Marechaud R, Rambaud JC, Matuchansky C. Manifestations intestinales des affections thyroïdiennes. Aspects cliniques et physiopathologiques actuels. Gastroenterol Clin Biol 1980; 4: 899-910.

3 Steinfeld CM, Moertel CG, Wollner LB. Diarrhea and medullary carcinoma of the thyroid. Cancer 1973; 31: 1237-9.

4 Saad MF, Ordonez NG, Rasmid RK, et al. Medullary carcinoma of the thyroid. Medicine 1984; 63: 319-42.

5 Bernier JJ, Rambaud JC, Cattan D, Prost A. Diarrhoea associated with medullary carcinoma of the thyroid. Gut 1969; 10: 980-5.

6 Gray TK, Brannan P, Juan D, Morawski SG, Fordtran JS. Ion transport changes during calcitonin-induced intestinal secretion in man. Gastroenterology 1976; 71: 392-8.

7 Krejs GJ, Fordtran JS. Diarrhea. In: Sleisenger MH, Fordtran JS, eds. Gastrointestinal disease. Pathophysiology. Diagnosis. Management. Philadelphia: Saunders, 1983: 257-80.

8 Williams ED. Medullary carcinoma and other disorders involving calcitonin. In: DeGroot LJ, eds. Endocrinology. Vol 2. New York: Grune and Stratton, 1979: 777-92.

9 Kumar MA, Slack E, Edwards A, et al. A biological assay for calcitonin. J Endocrinol $1965 ; 33$ : 469-75.

10 Rambaud JC, Thiry Ch, Bernier JJ. Étude de l'absorption intestinale du sodium et du potassium par la perfusion intestinale de solutés isotoniques chez l'homme. Acta Gastro-enterol Belg 1973; 36: 9-29.

11 Modigliani R, Bernier JJ. Effets du glucose sur les mouvements nets et unidirectionnels de l'eau et des électrolytes dans l'intestin grêle de l'homme. Biol Gastroenterol 1972; 5: 165-74.

12 Ruskoné A, René E, Chayvialle JA, et al. Effect of somatostatin on diarrhea and on small intestinal water and electrolyte transport in a patient with pancreatic cholera. Dig Dis Sci 1982; 27: 459-66.

13 Emonts P, Vidon N, Bernier JJ, Rambaud JC. Étude sur 24 heures des flux liquidiens intestinaux chez l'homme normal par la technique de la perfusion lente d'un marqueur non absorbable. Gastroenterol Clin Biol 1979; 3: $139-46$.

14 Phillips SF, Giller J. The contribution of the colon to electrolyte and water conservation in man. $J$ Lab Clin Med 1967; 70: 686-98.

15 Goiffon R, Goiffon B, Fron G. Contribution à l'étude des électrolytes des selles. II. Mesure des cations $\mathrm{Na}, \mathrm{K}$, $\mathrm{Ca}, \mathrm{Mg}, \mathrm{NH}_{3}$. Gastroenterologia 1961; 69: 223-34.

16 Goiffon R, Goiffon B, Fron G. Contribtion à l'étude des électrolytes des selles. II. Mesure des anions. Gastroenterologia 1961; 69: 312-25.

17 Cummings JH, Wiggins HS. Transit through the gut measured by analysis of a single stool. Gut 1976; 17: 219-23.

18 Jian R, Pecking A, Najean Y, Bernier JJ. Étude de la progression d'un repas dans l'intestin grêle de l'homme par une méthode isotopique. Gastroenterol Clin Biol 1979; 3: 755-62.

19 Isaacs P, Whitaker SM, Turnberg LA. Diarrhea associated with medullary carcinoma of the thyroid. Gastroenterology 1974; 67: 521-6.

20 Cox TM, Fagan EA, Hillyard CJ, Allison DJ, Chadwick VS. Role of calcitonin in diarrhoea associated with medullary carcinoma of the thyroid. Gut 1979; 20: 629-33.

21 Debongnie JD, Phillips SF. Capacity of the human colon to absorb fluids. Gastroenterology 1978; 74: 698-703.

22 Palma R, Vidon N, Bernier JJ. Maximal capacity for fluid absorption in human bowel. Dig Dis Sci 1981: 26: 929-34.

23 Norman T, Otnes B. Intestinal ganglioneuromatosis, 
diarrhoea and medullary thyroid carcinoma. Scand $J$ Gastroenterol 1969; 4: 553-9.

24 Krejs GJ, Hendler RS, Fordtran JS. Diagnostic and pathophysiologic studies in patients with chronic diarrhea. In: Fields M, Fordtran JS, Schultz SC, eds. Secretory diarrhea. Baltimore: American Physiological Society, Waverly Press Inc, 1980: 141-51.

25 Rubinstein $\mathrm{R}$, Howard AV, Wrong OM. In vivo dialysis of faeces as a method of stool analysis. IV. The organic anion component. Clin Sci 1969; 37: 549-64.

26 Read NW, Miles CA, Fisher D, et al. Transit of a meal through the stomach, small intestine and colon in normal subjects and its role in the pathogenesis of diarrhea. Gastroenterology 1980, 79: 1276-82.

27 Hill CS, Ibanez ML, Naguib AS, Ahearn MJ, Clark RL. Medullary (solid) carcinoma of the thyroid gland: an analysis of the M.D. Anderson Hospital experience with patients with tumor, its special features, and its histogenesis. Medicine 1973; 52: 141-71.

28 Tobler PH, Tschopp FA, Cambacher MA, Born W, Fischer JA. Identification and characterization of calcitonin forms in plasma and urine of normal subjects and medullary carcinoma patients. J Clin Endocrinol Metab 1983; 57: 749-54.

29 Austin LA, Heath H. Calcitonin. Physiology and pathophysiology. N Engl J Med 1981; 304: 269-78.

30 Bieberdorf FA, Gray K, Walsh JH, Fordtran JS. Effect of calcitonin on meal-stimulated gastric acid secretion and serum gastrin concentration. Gastroenterology 1974; 66: 343-6.

31 Williams ED, Karim SMM, Sandler M. Prostaglandin secretion by medullary carcinoma of the thyroid. A possible cause of the associated diarrhoea. Lancet 1968; i: $22-3$.

32 Barrowman JA, Bennett A, Hillebrand P, Kolles $\mathrm{K}$, Pollock DJ, Wright JT. Diarrhoea in thyroid medullary carcinoma: role of prostaglandins and therapeutic effect of nutmeg. Br Med J 1975; iii: 11-2.

33 Moertel CG, Beahr OH, Woolner LB, Tyce GM. Malignant carcinoid syndrome associated with noncarcinoid tumors. $N$ Engl J Med 1965: 273: 244-8.

34 Skrabanek P, Cannon D, Dempsey J, Kirrane J, Neligan $M$, Powel D. Substance P in medullary carcinoma of the thyroid. Experientia 1979 35: 1259-60. 